\title{
The study of plant density and planting methods on some growth characteristics, seed and oil yield of medicinal pumpkin (Cucurbita pepo var. styriaca, cv. 'Kaki)
}

\author{
Mahnaz Bahlgerdi ${ }^{*}$, Hossein Aroiee, Majid Azizi \\ Department of Horticultural Sciences Faculty of Agriculture, Ferdowsi University of Mashhad, Mashhad, Iran \\ Email address: \\ mahnaz.bahlgerdi@gmail.com (M. Bahlgerdi)
}

\section{To cite this article:}

Mahnaz Bahlgerdi, Hossein Aroiee, Majid Azizi. The Study of Plant Density and Planting Methods on Some Growth Characteristics, Seed and Oil Yield of Medicinal Pumpkin (Cucurbita Pepo Var. Styriaca, Cv. 'Kaki). American Journal of Life Sciences.

Vol. 2, No. 5, 2014, pp. 319-324. doi: 10.11648/j.ajls.20140205.21

\begin{abstract}
The effect of plant densities $\left(2,2.5,3\right.$ plant $\left./ \mathrm{m}^{2}\right)$ and two methods of planting (transplanting and direct seeding) were investigated on some growth characteristics, seed and oil yield of medicinal pumpkin (Cucurbita pepo var. styriaca, cv. ' $K a k i$ ). The experiment was carried out in a factorial trial based on complete randomized block design, with three replicates during spring and summer 2013. When the weather condition became suitable and seedlings were at true four leaves stage, both seeds and seedlings were planted at the same time in the farm. The results showed 2 plant $/ \mathrm{m}^{2}$ density had significant effect on plant lenght, leaf number, node number and sub branch number. Planting method also affected significantly on plant growth, so that the highest node number was achieved by using transplanting method. Plant density and planting method had significant effect on the oil content, so that the highest oil content was achieved by transplanting method with 2 plant $/ \mathrm{m}^{2}$ density. Also the most seed and oil yield obtained from transplanting method. Thus transplanting method had higher yields and its may be as a more reliable production method.
\end{abstract}

Keywords: Medicinal Pumpkin, Plant Density, Transplanting, Direct Seeding, Seed Yield

\section{Introduction}

Cucurbita pepo var. styriaca, cv. 'Kaki is one of the valuable medicinal plants in the pharmaceutical industry in most developed countries, which from 2000 years before Christ was cultivated in Peru, and South America is certainly the country of origin [1]. This plant is just a few years that have been studied from different perspectives with the aim of extracting and processing of the active ingredients are grown in Iran. The purpose of this reviews to obtain the methods to increase crop yield and plant active ingredients. Therefore, adjusting the distance between plants and changes in plant density per unit area is a powerful tool for controlling the competition between plant species [2]. An experiment was conducted to study plant density and phosphate on cucurbita pepo var styriaca, the highest seed dry weight per plant from 10000 plant/ha plant density, with an average $91.2 \mathrm{gr}$ and the lowest from $16,000 \mathrm{plant} / \mathrm{ha}$ plant density with an average 56 gr [3]. In Other research the most seed and fruit yield was achieved from cultivated plants with distance of $250 \mathrm{~cm}$ between rows and $50 \mathrm{~cm}$ row spacing [4]. In other research the highest seed yield (650 kg per hectare) was achieved from $300 \mathrm{~cm}$ spacing between lines and $55 \mathrm{~cm}$ on the lines of planting [5]. Density has several effects on crop yield at medicinal plants, because the aim of appropriate spacing between plants is to provide an appropriate combination of environmental factors (water, climate, light and soil) for maximum performance with optimum quality. [6] the effect of plant density on the oil percentage of Nigella sativa examined and reported that by increasing plant density, oil yield increased, although the amount of extracted oil in plant at lower plant density was higher. Transplant production has replaced direct seeding for many vegetable crops. One of the primary advantages offered by transplanting is earlier fruit production, allowing growers to capture better market conditions. Inaddition, the high cost of hybrid seed makes it desirable to use each seed as efficiently as possible. Transplanting also gives the crops a competitive advantage against weeds. [7] studied the effect of direct sowing, sowing pre-germinated seeds, and transplantations of seedlings of oil pumpkins on growth, yield and production costs in three 
years of field experiments. Plants that developed from transplanted seedlings were luxuriant and produced more and larger fruits than those grown from direct sowing. The seed yield obtained from transplants was significantly higher $\left(3.35 \mathrm{~kg} 20 \mathrm{~m}^{-2}\right)$ than that obtained from direct sowing $(2.06$

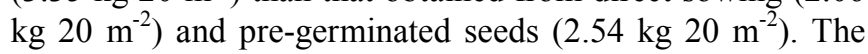
break-even price per $\mathrm{kg}$ seed yield from direct sowing $(0.98$ EUR $\mathrm{kg}^{-1}$ seed yield) was lower than the costs from transplanted seedlings $\left(1.20 \mathrm{EUR} \mathrm{kg}^{-1}\right)$ where the profit ha ${ }^{-1}$ was higher. [8] evaluated the effect of planting methods (seed sowing and transplanting) on yield and yield components such as number of branches (sub-branches) per plant, fruits per plant, growth, fruit size, weight of fresh fruit, weight of seeds per fruit, number of seeds per fruit and seed yield of medicinal pumpkin. Results showed that the planting methods had significant effect on the number of ripen fruits per plant, fruits diameter, weight of seeds per fruit, weight of 1000 seeds and seed yield and had no significant effect on the other traits.

\section{Materials and Methods}

To study the effect of plant density and planting method on some growth characteristics, seed and oil yield of medicinal pumpkin (Cucurbita pepo var. styriaca, cv. 'Kaki) experiment was carried out in a factorial trial based on complete randomized block design, with three replicates in Department of Agriculture of Ferdowsi University of
Mashhad, during spring and summer 2013. The factors include planting methods (seed sowing and transplanting) and plant density $\left(2,2.5,3 \mathrm{plant} / \mathrm{m}^{2}\right)$. Stack width was 200 $\mathrm{cm}$ and bilateral planting pattern by three replications. Surface irrigation was practiced every day until the seeds sprouted and then whenever it was needed and weeding was handy. From two to four weeks before transplanting, should prepare seedlings in small pots. When the weather condition became suitable and seedlings were at the four leaves stage, both seeds and seedlings were planted at the same time in the farm. Sampling was performed at three stages of flowering, fruiting and ripening. Plant length, number of leaf, number of node and number of sub branch were measured. At ripening stage, seed yield, oil yield and oil percentage, number of seed, weight of 1000 seeds, weight of fruit, number of fruit per plant in each treatment was assessed. Seed oil by using soxhlet and hexane solvent were measured. The oil content of the seeds was determined by treating the weighted powder seeds with hexane and refluxed for $4 \mathrm{~h}$ in a soxhlet extractor. The solvent was removed by rotary evaporator. Statistical analysis of the data based on a factorial experiment in a randomized complete block design and the Least Significant Difference (LSD) test was used to separate the means at $\mathrm{p}<0.05$ by the software JMP 8 .

\section{Results and Discussion}

\subsection{Vegetative Traits}

Table 1. Results of variance analysis of planting method and planting spaces on studied traits at flowering stage

\begin{tabular}{|c|c|c|c|c|c|}
\hline SOV & df & Number of Leaf per plant & Number of Node per main stem & Sub branch Per plant & Plant length \\
\hline $\mathrm{R}$ & 2 & 0.38 & 1.72 & 0.05 & 17.54 \\
\hline $\mathrm{P}$ & 1 & $46.72^{\mathrm{ns}}$ & $26.88^{* *}$ & $2.72^{* *}$ & $0.68^{\mathrm{ns}}$ \\
\hline $\mathrm{D}$ & 2 & $147.38^{* *}$ & $26.72^{* *}$ & $0.88^{*}$ & $1210.29^{* *}$ \\
\hline $\mathrm{P} * \mathrm{D}$ & 2 & $5.38^{\mathrm{ns}}$ & $1.72^{\mathrm{ns}}$ & $0.22^{\mathrm{ns}}$ & $10.68^{\mathrm{ns}}$ \\
\hline Error & 10 & 9.65 & 0.52 & 0.18 & 4.54 \\
\hline
\end{tabular}

R: Replication, P: Planting method, D: Density, $\mathrm{P}^{*} \mathrm{D}$ : Interaction between P and D, ns: Not significant, ${ }^{*}:$ Significant in $5 \%$ probability level, ${ }^{* *}$ : Significant in $1 \%$ probability level

Table 2. The effect of planting methods on the studied traits

\begin{tabular}{|c|c|c|c|c|}
\hline Planting method & Number of Leaf per plant & Number of Node per main stem & Sub branch Per plant & Plant length $(\mathrm{cm})$ \\
\hline Transplanting & $17.33 \mathrm{a}$ & $11.77 \mathrm{a}$ & $2.33 \mathrm{a}$ & $48.22 \mathrm{a}$ \\
\hline Direct seeding & $14.11 \mathrm{a}$ & $9.33 b$ & $1.55 \mathrm{~b}$ & $48.61 \mathrm{a}$ \\
\hline
\end{tabular}

Table 3. The effect of plant density on the studied traits

\begin{tabular}{|c|c|c|c|c|}
\hline Plant density & Number of Leaf per plant & Number of Node per main stem & Sub branch Per plant & Plant length $(\mathrm{cm})$ \\
\hline 2 plant $/ \mathrm{m} 2$ & $21 \mathrm{a}$ & $12.83 \mathrm{a}$ & $2.16 \mathrm{a}$ & $64.16 \mathrm{a}$ \\
\hline 2.5 plant $/ \mathrm{m} 2$ & $15 \mathrm{~b}$ & $10.16 b$ & $2.16 \mathrm{a}$ & $44.50 \mathrm{~b}$ \\
\hline 3 plant $/ \mathrm{m} 2$ & $11.16 \mathrm{~b}$ & $8.66 \mathrm{c}$ & $1.50 \mathrm{~b}$ & $36.58 \mathrm{c}$ \\
\hline
\end{tabular}

The plant length was significantly influenced by plant density, so that the $50 \mathrm{~cm}$ distances ( 2 plant $/ \mathrm{m}^{2}$ density) with a mean plant length of $64.16 \mathrm{~cm}$ was significantly higher than 30 and $40 \mathrm{~cm}$ distances. This result is consistent with the result of [3]. Increasing plant density resulted in increasing space, water and food for the plants and enhances the growth of plants, thus increase the length of the plant. Planting method and plant density had a significant effect on the number of node per main stem (table 1), The highest number of node (11.77 node/main stem) obtained from transplanting method and the lowest number ( 9.33 node/main stem) obtained from direct seeding. Between plant density treatments, the higher number of node per main stem $(12.83$ node/main stem) obtained from $50 \mathrm{~cm}$ distances $\left(2 \mathrm{plant} / \mathrm{m}^{2}\right.$ density) and the least number (8.66 node/main stem) obtained from $30 \mathrm{~cm}$ distances ( 3 plant $/ \mathrm{m}^{2}$ density). This 
result is consistent with the result of [3]. Increasing plant density resulted in increasing space, water and food for the plants and enhanced the nodes of plants. Plant density had a significant effect on the number of leaf per plant (table 1), the highest number of leaf (21 leaf/plant) obtained from 50 $\mathrm{cm}$ distances ( 2 plant $/ \mathrm{m}^{2}$ density) and 30 and $40 \mathrm{~cm}$ distances $\left(3,2.5 \mathrm{plant} / \mathrm{m}^{2}\right.$ densities) had no significant difference (table 1 ), it is because of more number node in this distance. This result is in agreement with several investigators $[3,9,10]$. Planting method and plant density had a significant effect on the sub branches per plant at flowering stage. The results showed that the number of sub branch per plant was affected from planting method and the higher number $(2.33$ branch/plant) obtained from transplanting method and the least number (1.55 branch/plant) obtained from direct planting (seed sowing). Between plant density treatments, the higher number of sub branch per plant (2.16 branch/plant) obtained from $50 \mathrm{~cm}$ and $40 \mathrm{~cm}$ distances $\left(2,2.5 \mathrm{plant} / \mathrm{m}^{2}\right.$ density) and the least number (1.50 branch/plant) obtained from $30 \mathrm{~cm}$ distances ( 3 plant $/ \mathrm{m}^{2}$ density). This result is consistent with the results of $[3,9,10,11]$ in their study. Increasing plant density resulted in increasing space, water and food for the plants and enhanced the sub branch of plants.

The plant density had a significant effect on the plant length at fruiting stage, so that the highest plant length $\left(191.66 \mathrm{~cm}\right.$ ) obtained from the $2 \mathrm{plant} / \mathrm{m}^{2}$ density (table 4$)$, it is because of more number node in this distance. Decreasing plant density resulted in increasing the vegetative growth of the plants and reducing the reproductive growth which leading to decreased competition between plants and increase the vegetative growth of the plants and thus increase the length. This result is consistent with the result of [3]. The number of node per main stem was affected by planting method and plant density. The highest number of node per main stem with an average of 37 node obtained from the 2 plant $/ \mathrm{m}^{2}$ density and $2.5,3$ plant $/ \mathrm{m}^{2}$ densities with an average of 35.66 node and 30.83 node per main stem were placed another group. Increasing plant density resulted in increasing space, water and food for the plants and enhanced the nodes of plants. This result is consistent with the result of [3]. The highest number of node (36.22 node/main stem) obtained from transplanting method and the lowest number (32.77 node/main stem) obtained from direct seeding. Plant density had a significant effect on the number of leaf per plant, so that comparison of plant densities showed that the 2 plant $/ \mathrm{m}^{2}$ density with a mean leaf per plant of 59.16 was significantly higher than $2.5,3$ plant $/ \mathrm{m}^{2}$ densities. With decreasing plant density, because of increasing space for expansion of the plants and food and other environmental factors resulted in increasing the length of the plant, the number of nodes and the number of sub branches and thus increase the number of leaves. This result is consistent with the results of $[3,9,10]$ in their study. The sub branch was significantly influenced by plant density, so that the 2 plant $/ \mathrm{m}^{2}$ density with a mean sub branch of 9.66 branch per plant was significantly higher than $2.5,3$ plant $/ \mathrm{m}^{2}$ densities and the $2.5,3$ plant $/ \mathrm{m}^{2}$ densities had no significant difference (table 4). This difference in the number of sub branch of plants, is because of an increase in water and food and distances between plants. This result is consistent with the results of $[3,9,10,11]$ in their study.

Table 4. Results of variance analysis of planting method and planting spaces on studied traits at fruiting stage

\begin{tabular}{|c|c|c|c|c|c|}
\hline SOV & df & Number of Leaf per plant & $\begin{array}{l}\text { Number of Node per main } \\
\text { stem }\end{array}$ & Sub branch Per plant & Plant length \\
\hline $\mathrm{R}$ & 2 & 20.22 & 15.16 & 7.16 & 612.50 \\
\hline$P$ & 1 & $20.05^{\mathrm{ns}}$ & $53.38^{* *}$ & $0.50^{\mathrm{ns}}$ & $1012.50^{\mathrm{ns}}$ \\
\hline $\mathrm{D}$ & 2 & $714.05^{* *}$ & $63.16^{* *}$ & $30.16^{* *}$ & $7454.16^{*}$ \\
\hline $\mathrm{P} * \mathrm{D}$ & 2 & $15.38^{\mathrm{ns}}$ & $1.05^{\mathrm{ns}}$ & $0.16^{\mathrm{ns}}$ & $304.16^{\mathrm{ns}}$ \\
\hline Error & 10 & 45.35 & 4.23 & 2.50 & 1405.83 \\
\hline
\end{tabular}

R: Replication, P: Planting method, D: Density, P*D: Interaction between P and D, ns: Not significant, ${ }^{*}:$ Significant in $5 \%$ probability level, ${ }^{* *}$ : Significant in $1 \%$ probability level

Table 5. The effect of planting methods on the studied traits

\begin{tabular}{|c|c|c|c|c|}
\hline Planting method & Number of Leaf per plant & Number of Node per main stem & Sub branch Per plant & Plant length $(\mathrm{cm})$ \\
\hline Transplanting & $48.11^{\mathrm{a}}$ & $36.22^{\mathrm{a}}$ & $7^{\mathrm{a}}$ & $160^{\mathrm{a}}$ \\
\hline Direct seeding & $46^{\mathrm{a}}$ & $32.77^{b}$ & $7.33^{\mathrm{a}}$ & $145^{\mathrm{a}}$ \\
\hline
\end{tabular}

Table 6. The effect of plant density on the studied traits

\begin{tabular}{llll}
\hline Plant density & Number of Leaf per plant & Number of Node per main stem & Sub branch Per plant \\
\hline 2 plant $/ \mathrm{m}^{2}$ & $59.16^{\mathrm{a}}$ & $37^{\mathrm{a}}$ & $9.66^{\mathrm{a}}$ \\
$2.5 \mathrm{plant} / \mathrm{m}^{2}$ & $44^{\mathrm{b}}$ & $35.66^{\mathrm{a}}$ & $6.50^{\mathrm{b}}$ \\
3 plant $/ \mathrm{m}^{2}$ & $38^{\mathrm{b}}$ & $30.83^{\mathrm{b}}$ & $5.33^{\mathrm{b}}$ \\
\hline
\end{tabular}

\subsection{Seed Yield}

The results indicated that the planting method and plant density had a significant effect on the seed yield (table 7). The seed yield in transplanting method $(719.15 \mathrm{~kg} / \mathrm{ha}$ ) was significantly higher than direct planting $(527.68 \mathrm{~kg} / \mathrm{ha})$ (table 7). It is because of enough time for growth and ripening most of the fruits in transplanting method and increasing the weight of 1000 seeds. Increasing crop growth rate of seedlings during vegetative growth, early reproductive stage 
and also more absorption of light in the whole growing season, resulted in increasing seed yield. This result is consistent with the result of [8]. Considering significant effect of the number of fruit in increasing the seed yield of Cucurbita pepo var. styriaca and improving the number of fruit in case of planting bilaterally [12], if planting bilateral, increasing in the seed yield seems reasonable. Between plant densities, the highest seed yield $(880.72 \mathrm{~kg} / \mathrm{ha})$ obtained from plant density of 3 plant $/ \mathrm{m}^{2}$ and the lowest seed yield (415.89 kg/ha) obtained from plant density of $2 \mathrm{plant} / \mathrm{m}^{2}$ (table 7). These results corresponded with the results of [13, $14]$.

[15] mentioned that a low seed yield per plant is due to small weight or quantity of fruits in high density planting. High plant population causes competition for place, light and nutrients resulting in a lower seed production per fruit and per plant, and small fruits with lower weight.

\subsection{Number of Fruits Per Plant}

The results showed that the number of fruits was affected from plant density and the higher number (2.07 fruit/plant) obtained from 2 plant $/ \mathrm{m}^{2}$ density and the least number $(0.99$ fruit/plant) obtained from 3 plant $/ \mathrm{m}^{2}$ (table 7). These results corresponded with the results of [13] on Cucumber; [14] on Cucumber; [16] on Cucumber; [17] on Cucumber; [18] on Cucumber; [19] on Cucumber; [20] on Muskmelon. Increasing density reduces the production of biomass and reduce the production of fruits per plant. Probably the increasing competition for place, light and nutrients reduced fruit set, influencing the number of fruits per plant.

\subsection{Weight of Fruit}

The results showed that the planting method and plant density had a significant effect on the weight of fruit. The weight of fruit in transplanting method was $1.56 \mathrm{~kg}$ and it was $1.30 \mathrm{~kg}$ in direct planting (table 7). Between plant densities, the highest weight of fruit $(1.76 \mathrm{~kg})$ obtained from plant density of 2 plant $/ \mathrm{m}^{2}$ and plant densities of $2.5,3$ plant $/ \mathrm{m}^{2}$ had no significant different (table 7). This results is consistent with the results of [13] on Cucumber; [14] on Cucumber; [20] on Muskmelon; [21] on Cucumber; [22] on Squash. There was a general tendency of decrease in seed number per fruit and in the mean seed weight by increasing plant density. With decreasing plant density, because of increasing space for expansion of the plants and food and other environmental factors resulted in increasing the weight of fruit. Also increasing the weight of fruit at transplanting method because of preparing enough time to maturing and ripening the fruits by transplanting method that resulted in increasing fruit size.

\subsection{Weight of 1000 Seeds}

The results showed that the planting method and plant density had a significant effect on the weight of 1000 seeds. The weight of 1000 seeds in transplanting method was $140.05 \mathrm{gr}$ and it was $101.71 \mathrm{gr}$ in direct planting (table 7). This result is consistent with the result of [10]. Between plant densities, the highest weight of 1000 seeds (143.48 gr) obtained from plant density of 2 plant $/ \mathrm{m}^{2}$ and plant densities of 2.5, 3 plant $/ \mathrm{m}^{2}$ had no significant different (table 7). This result is consistent with the result of [12]. Effects of interaction between treatments on the weight of 1000 seeds were significant, so that the highest weight of 1000 seeds (179.01 gr) obtained from transplanting with a density 2 plant $/ \mathrm{m}^{2}$ and the lowest obtained from direct planting with a density 2.5 plant $/ \mathrm{m}^{2}$ (96.59 gr) (table 7$) .2$ plant $/ \mathrm{m}^{2}$ density via increasing the photosynthesis area and increase the power source and enhance the relationship between source and destination resulting in increasing weight of 1000 seeds.

\subsection{Number of Seeds}

The results showed that the number of seeds per fruit was affected from planting method and the higher number (268.44 seed/fruit) obtained from transplanting method and the least number (220.33 seed/fruit) obtained from direct planting. It is because of preparing enough time to maturing and ripening the fruits by transplanting method that resulted in increasing fruit size and formation of more seeds per fruit. This result is consistent with the result of [8].

\subsection{Oil Content}

The effect of plant density on the oil percent was significant, Between plant densities, the highest oil percent $(46.48 \%)$ obtained from plant density of 2 plant $/ \mathrm{m}^{2}$ and plant densities of $2.5,3$ plant $/ \mathrm{m}^{2}$ had no significant different, so that increase in row distance from $30 \mathrm{~cm}$ to $50 \mathrm{~cm}$, became causing an increase of oil percent from 41.45 percent to 46.48 percent (table 7). More row spacing, resulting in an increase of $5 \%$ oil compared with lower row spacing. The oil percent was influenced from interaction between treatments and the most oil percent obtained from transplanting with 2 plant $/ \mathrm{m}^{2}$ density $(51.70 \%)$ (table 3$)$.

\subsection{Oil Yield}

Table 7. Results of variance analysis of planting method and planting spaces on studied traits at ripening stage

\begin{tabular}{|c|c|c|c|c|c|c|c|c|}
\hline SOV & df & Number of fruit & Weight of fruit & Oil percent & Seed yield & Oil yield & Number of seeds per fruit & Weight of 1000 seeds \\
\hline $\mathrm{R}$ & 2 & 0.003 & 0.05 & 18.04 & 2493.9 & 413.99 & 1407.05 & 400.85 \\
\hline$P$ & 1 & $0.0006^{\mathrm{ns}}$ & $0.29^{* *}$ & $3.67^{\mathrm{ns}}$ & $164982.0^{* *}$ & $26821.79^{* *}$ & $10416.05^{*}$ & $6614.80^{* *}$ \\
\hline $\mathrm{D}$ & 2 & $2.02^{* *}$ & $0.53^{* *}$ & $46.56^{*}$ & $335248.8^{* *}$ & $34388.45^{* *}$ & $1040.05^{\mathrm{ns}}$ & $2344.59^{* *}$ \\
\hline $\mathrm{P} * \mathrm{D}$ & 2 & $0.0005^{\mathrm{ns}}$ & $0.008^{\mathrm{ns}}$ & $102.18^{*}$ & $6932.6^{\mathrm{ns}}$ & $730.61^{\mathrm{ns}}$ & $555.72^{\mathrm{ns}}$ & $1340.43^{* *}$ \\
\hline Error & 10 & 0.002 & 0.02 & 8.03 & 3034 & 353.2 & 1492.26 & 151.67 \\
\hline
\end{tabular}

R: Replication, P: Planting method, D: Density, P*D: Interaction between P and D, ns: Not significant, ${ }^{*}$ : Significant in $5 \%$ probability level, ${ }^{* *}$ : Significant in $1 \%$ probability level 
Table 8. The effect of planting methods on the studied traits

\begin{tabular}{|c|c|c|c|c|c|}
\hline Planting method & Oil percent & Seed yield (kg/ha) & Oil yield (kg/ha) & Number of seeds per fruit & Weight of 1000 seeds \\
\hline Transplanting & $43.72^{\mathrm{a}}$ & $719.15^{\mathrm{a}}$ & $287.97^{\mathrm{a}}$ & $268.44^{\mathrm{a}}$ & $140.05^{\mathrm{a}}$ \\
\hline Direct seeding & $42.82^{\mathrm{a}}$ & $527.68^{\mathrm{b}}$ & $210.77^{b}$ & $220.33^{b}$ & $101.71^{\mathrm{b}}$ \\
\hline
\end{tabular}

Table 9. The effect of plant density on the studied traits

\begin{tabular}{|c|c|c|c|c|c|}
\hline Plant density & Oil percent & Seed yield $(\mathrm{kg} / \mathrm{ha})$ & Oil yield (kg/ha) & Number of seeds per fruit & Weight of 1000 seeds \\
\hline 2 plant $/ \mathrm{m}^{2}$ & $46.48^{\mathrm{a}}$ & $415.89^{c}$ & $190.71^{\mathrm{c}}$ & $255.83^{\mathrm{a}}$ & $143.48^{\mathrm{a}}$ \\
\hline 2.5 plant $/ \mathrm{m}^{2}$ & $41.88^{\mathrm{b}}$ & $573.64^{\mathrm{b}}$ & $222.57^{\mathrm{b}}$ & $247.33^{\mathrm{a}}$ & $112.36^{\mathrm{b}}$ \\
\hline 3 plant $/ \mathrm{m}^{2}$ & $41.45^{\mathrm{b}}$ & $880.72^{\mathrm{a}}$ & $334.83^{\mathrm{a}}$ & $230.00^{\mathrm{a}}$ & $106.81^{\mathrm{b}}$ \\
\hline
\end{tabular}

The results showed that the oil yield was affected from planting method and plant density. The higher oil yield $(287.97 \mathrm{~kg} / \mathrm{ha})$ obtained from transplanting method and the least oil yield $(210.77 \mathrm{~kg} / \mathrm{ha})$ obtained from direct planting (seed sowing). The results of research on (Sesamum indicum L.) also showed that there is a positive correlation between seed yield and oil yield [23]. Between plant densities, the highest oil yield (334.83 kg/ha) obtained from plant density of 3 plant $/ \mathrm{m}^{2}$ and the lowest oil yield (190.71 kg/ha) obtained from plant density of 2 plant $/ \mathrm{m}^{2}$ (table 9). Cucurbita pepo var styriaca is a creeper and indeterminate plant [24], its oil is of the great importance in term of medicinal consumption. Thus, using of the appropriate density can be improve the vegetative growth and followed by the economic performance of the medicinal plant. The oil yield is affected of the seed yield and the seed yield is affected by the number of fruit and intra row space and planting pattern is affected of the number of fruit. Considering a positive correlation between the number of fruit and seed yield and oil yield of Cucurbita pepo var styriaca, So seems can enjoying a proper agronomic management Such as adjustment of intra row space and appropriate planting, because of decreasing in vegetative growth result in increasing the seed yield and oil yield.

\section{Conclusion}

Cucurbita pepo var styriaca is a creeper and indeterminate plant, its oil is of the great importance in term of medicinal consumption. Thus, using of the appropriate density can be improve the vegetative growth and followed by the economic performance of the medicinal plant. The oil yield is affected of the seed yield and the seed yield is affected by the number of fruit and intra row space and planting pattern is affected of the number of fruit. Considering a positive correlation between the number of fruit and seed yield and oil yield of Cucurbita pepo var styriaca, So seems can enjoying a proper agronomic management Such as adjustment of intra row space and appropriate planting, because of decreasing in vegetative growth result in increasing the seed yield and oil yield. Pumpkins are generally established via direct seeding however they can be sown as transplants. The results of present investigation detected that transplanting method and plant density resulting in increasing the seed and oil yield. So that, the highest seed and oil yield obtained from transplanting method. It is because of preparing enough time to maturing and ripening the fruits by transplanting method that resulted in increasing fruit size and formation of more seeds per fruit. It seems that plant density of 3 plant $/ \mathrm{m}^{2}$ is most appropriate for several agricultural characteristics of pumpkin seed, specially seed and oil yield.

\section{Acknowledgments}

I profoundly thanks from Dr. Hossein Aroiee to complete this work successfully.

\section{References}

[1] Wagner, F.S. 2000. The health value of styrian pumpkin-seed oilscince and fiction. Cucurbit Genetics Cooprative, 23: 122-123.

[2] Hornok, L. 1986. Effect of environmental factors on growth yield and the active principles of some spice plants. Acta Horticulturae, 188: 169-176.

[3] Moazzen, Sh., Daneshian, J., Valadabad, S.A., and Baghdadi, H. 2006. Study of plant and phosphate fertilization on some agronomic characters and seed and fruit yield of pumpkin (Cucurbita pepo L.). Iranian Journal of Medicinal and Aromatic Plants 22(4): 397-409. (In Persian with English Summary).

[4] Aroiee, H., Omid-Beigi, R. \& Kashi, A. (2000): Effect of nitrogen levels on some characteristics of cucurbita pepo. Journal of Pajuhesh and Sazandegi. 48: 4-9.

[5] Baghdadi, H., 2003. Evaluation of planting date and density on seed yield of pumpkin. $2^{\text {nd }}$ of Congress on Medicinal plants, Tehran, Iran. pp. 68. (In Persian).

[6] Ahmad, N.U. and Haque, K.R. 1986. Effect of row spacing and time of sowing on the yield of black cumin ( Nigella sativa L.). Bangladesh. J.Agris, 1:21-24.

[7] Bavec, F., L. Gril, S. Grobelnik Mlakar, and M. Bavec. 2002b. Seedlings of oil pumpkins as an alternative to seed sowing: Yield and production costs. Die Bodenkultur 53:39-42.

[8] Nikkhah Bahrami, R .,khodadadi, M., PiryPirivatlo, S., Hassanpanah, D. 2009. The Effects of Planting Methods and Head Pruning on Seed Yield and Yield Components of Medicinal Pumpkin (Cucurbita pepo subsp. Pepoconvar. Pepovar. styriaca) at Low Temperature Areas. Pakistan Journal of Biological sciences, 12: 538-541.

[9] Ebadi, M., Gholipoori, A., and Nikkhah Bahrami, R. 2008. The effect of pruning and distance between plants on yield and yield components of pumpkin (Cucurbita pepo L.). Pajouhesh v Sazandegi 21(1): 41-(In Persian with English Summary). 
[10] Sajed, M. A., Hosseini Moghaddam, H., Yazdani, D., Ahmadi, P. 2001. Effect of soil plastic cover and planting spacing and the amount of phosphate fertilizer on growth and seed and oil yield of medicinal pumpkin. $2^{\text {nd }}$ of Congress on Medicinal plants, Tehran, Iran. pp. 188. (In Persian).

[11] Melissa, W.A.L., Allison, R., Kenneth, R.J., and Barbara, Z.A. 2008. The effects of repeated planting, planting density, and specific transfer pathways on PCB uptake by Cucurbita pepo grown in field conditions. Science of the Total Environment 405(1-3): 14-25.

[12] Ghanbari, A., Nadjafi, F., and Shabahang, J. 2007. Effects of irrigation regimes and row arrangement on yield, yield components and seed quality of pumpkin (Cucurbita pepo L.). Asian Journal of Plant Sciences 6(7): 1072-1079.

[13] Staub, J., L. Knerr and H. Hopen. 1992. Plant density and herbicides affect cucumber productivity. J. Amer. Soc. Hort. Sci. 117: 48-53.

[14] Enthoven, N. 1980. Planting distance and stem system in autumn cucumber. Groenten en Fruit. 35: 30-31.

[15] Loy, J. B. Improving seed yield in hull-less seeded strains of Cucurbita pepo. Cucurbit Genetics Cooperative, n. 11, p. 7273, 1988.

[16] Nemati, H., Esmaili, A. A., Davarinezhad, Gh., Farsi, M. 2011. Effects of pruning and plant density on traits of three cultivars of of greenhouse cucumber. Journal of Horticultural Science, Vol. 25 (1): 9-17.

[17] Cantliffe, D.J. and S.C. Phatak. 1975. Plant population studies with pickling cucumbers grown for once-over harvest. J.
Amer. Soc. Hort. Sci. 100: 464-466.

[18] Sullivan, J.O. 1980. Irrigation, spacing and nitrogen effects on yield and quality of pickling cucumbers grown for mechanical harvesting. Can. J. Plant Sci. 60: 923-928.

[19] Widders, I.E. and H.C. Price. 1989. Effects of plant density on growth and biomass partitioning in pickling cucumbers. J. Amer. Soc. Hort. Sci. 114: 751-755.

[20] Mendlinger, S. 1994. Effect of increasing plant density and salinity on yield and fruit quality in muskmelon. Sci. Hort. 57: 41-49.

[21] Bakker, J. and J.V.D. Vooren. 1985. Plant densities and training systems of greenhouse cucumber. Acta Hort. 156: 4348.

[22] Nerson. H. 2005. Effect of fruit shape and plant density on seed yield and quality of squash. Science Horticulturae 105: 293-304.

[23] Rezvani Moghaddam, P., Norozpoor, G., Nabati, J., and Mohammad Abadi, A.A. 2005. Effects of different irrigation intervals and plant density on morphological characteristics, grain and oil yields of sesame (Sesamum indicum). Iranian Journal of Field Crops Research 3(1): 57-68. (In Persian with English Summary).

[24] Omid Beygi, R. 1995. Approaches to Producing and Processing of Medicinal Plants. Fekr Rooz Publication (In Persian). 